\title{
Photooxygenation of chiral 1,3-cyclohexadienes: strong influence of substituents on the stereo- and mode selectivities
}

\author{
Torsten Linker, ${ }^{a^{*}}$ Tobias Krüger, ${ }^{a}$ Wilfried Hess, ${ }^{b}$ and Gerhard Hilt ${ }^{b}$ \\ ${ }^{a}$ Institute of Chemistry, University of Potsdam, Karl-Liebknecht-Str. 24-25, \\ 14476 Potsdam/Golm, Germany \\ E-mail: linker@chem.uni-potsdam.de \\ ${ }^{b}$ Fachbereich Chemie Philipps-Universität Marburg, Hans-Meerwein-Str., \\ 35043 Marburg, Germany \\ E-mail: hilt@chemie.uni-marburg.de
}

Dedicated to Professor Waldemar Adam on the occasion of his $\mathbf{7 0}^{\text {th }}$ birthday

\begin{abstract}
Four different chiral 1,3-cyclohexadienes were synthesized and investigated in photooxygenations with singlet oxygen. A strong influence of substituents at the double bond was observed for the mode selectivity of the reactions. Phenyl and alkyl groups afford mixtures of ene and [4 +2] products, whereas a trimethylsilyl group yields exclusively hydroperoxides, presumably due to a "large group effect". Additionally, the same diastereoselectivity for both reaction modes gives evidence for common perepoxide intermediates. Finally, the photooxygenation of a methylensulfonyl substituted 1,3-cyclohexadiene proceeds with very high diastereoselectivity, which can be explained by an intramolecular hydrogen bridge, shielding one face of the compound.
\end{abstract}

Keywords: Cyclohexadienes, singlet oxygen, mode selectivity, stereoselectivity, reaction mechanisms

\section{Introduction}

Singlet oxygen $\left({ }^{1} \mathrm{O}_{2}\right)$ represents a powerful and atom-economic oxidant, which has found numerous applications in organic synthesis. ${ }^{1}$ The most convenient method for the generation of ${ }^{1} \mathrm{O}_{2}$ is the dye-sensitized photoreaction of molecular oxygen with visible light (photooxygenation). Alkenes react with ${ }^{1} \mathrm{O}_{2}$ by an ene-reaction to allylic hydroperoxides, whereas 1,3-dienes undergo predominantly [4+2]-cycloadditions to provide endoperoxides. ${ }^{2}$ Singlet-oxygen ene reactions with high diastereoselectivities are based on the pioneering work of 
Adam. ${ }^{3}$ On the other hand, the stereochemical course of [4+2]-cycloadditions of ${ }^{1} \mathrm{O}_{2}$ to cyclic 1,3-dienes was studied less intensively, although this reaction is known for many years. ${ }^{4}$ More recently, auxiliary controlled ${ }^{5}$ and even organocatalytic ${ }^{6}$ enantioselective photooxygenations were realized. Finally, singlet oxygen was applied for reversible light and air-driven lithography. ${ }^{7}$

During our work on synthetic applications of singlet oxygen, ${ }^{8}$ we found excellent regioand high diastereoselectivities in the photooxygenation of 1,4-cyclohexadienes $\mathbf{1}$, which are easily available by Birch reduction, to afford hydroperoxides 2 (Scheme 1). However, a direct comparison of ene-reaction versus [4+2]-cycloaddition was not possible with such systems. Therefore, we became interested in the photooxygenation of chiral 1,3-cylohexadienes, which allow the examination of stereo- and mode selectivities within the same molecule. Herein, we present our results on the addition of singlet oxygen to 1,3-cylohexadienes, which exhibits strong substituent effects.

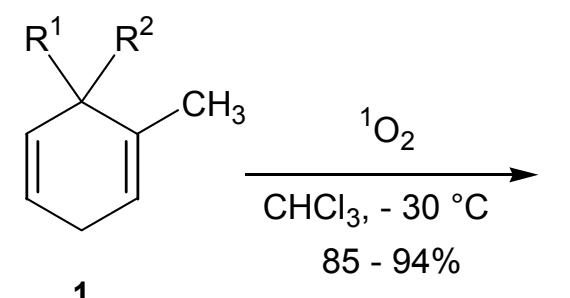

$\mathrm{R}^{1}=\mathrm{CO}_{2} \mathrm{H}, \mathrm{CO}_{2} \mathrm{Me}, \mathrm{CH}_{2} \mathrm{OH}$ $\mathrm{R}^{2}=\mathrm{Me}, \mathrm{Et}, i-\mathrm{Pr}$

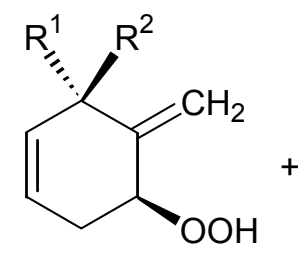

trans-2 $d r=88: 12 \rightarrow<4: 96$

\section{Scheme 1}

\section{Results and Discussion}

For the convenient synthesis of cyclohexadienes, we developed a new cobalt-catalyzed DielsAlder methodology, starting from a boron-functionalized 1,3-diene 3 and various alkynes $4 .{ }^{9}$ Very recently, we succeeded in a one-pot combination of this reaction with an allylboration in the presence of aldehydes $\mathbf{5}$, which afforded the desired 1,3-cyclohexadienes $\mathbf{6}$ from three simple precursors in moderate to good yields (Scheme 2). Furthermore, the reactions exhibit a high degree of diastereoselectivity and even asymmetric induction was achieved by chiral ligands. ${ }^{10}$ 


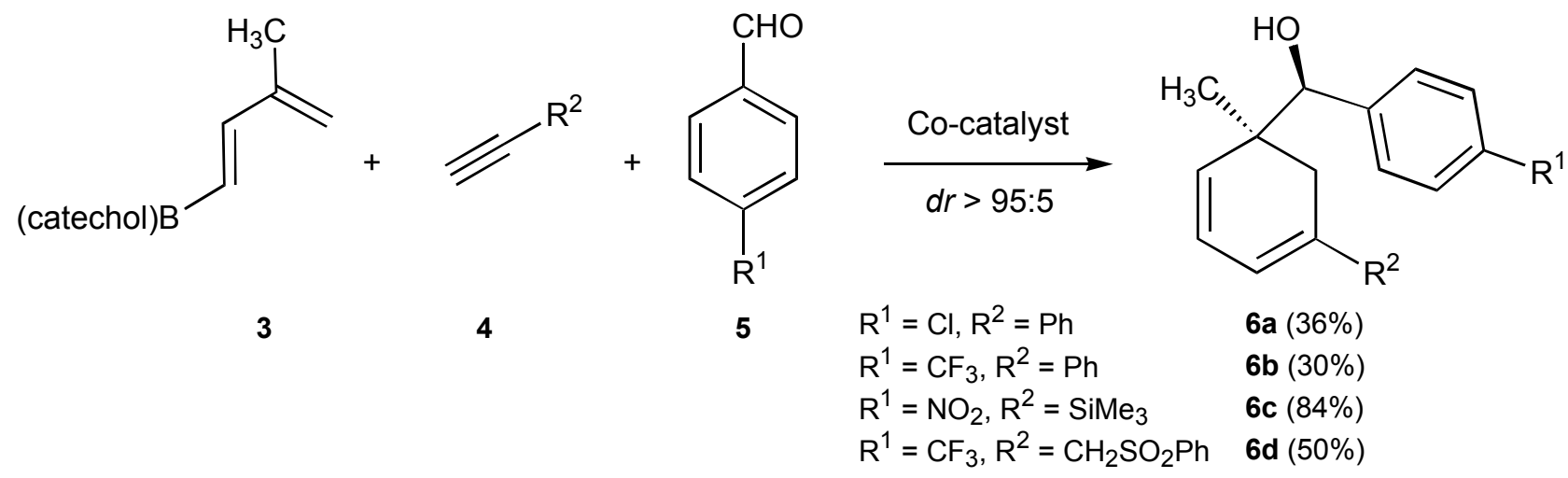

\section{Scheme 2}

For the photooxygenations, four differently substituted 1,3-cyclohexadienes 6a-d were chosen in racemic form, since only the diastereo- and mode selectivities were examined. Singlet oxygen was conveniently generated at $-30{ }^{\circ} \mathrm{C}$ from molecular oxygen by irradiation with two sodium lamps in the presence of catalytic amounts of tetraphenylporphine (TPP) as sensitizer. Complete conversion was achieved after $10 \mathrm{~min}$ in deuterochloroform as solvent and the product ratios were directly determined from the ${ }^{1} \mathrm{H}$ NMR spectra $(500 \mathrm{MHz})$ of the crude reaction mixture. The photooxygenations afforded hydroperoxides 7 and endoperoxides $\mathbf{8}$ in various ratios and the labile products were directly isolated by column chromatography in high yields and in analytically pure form (Table 1).

Table 1. Photooxygenation of the 1,3-cyclohexadienes 6<smiles>[R]C1=CC=C[C@](C)([C@H](O)c2ccc([R])cc2)C1</smiles>

\begin{tabular}{ccccccc}
\hline & & & & & \multicolumn{2}{c}{${\text { Yield }(\%)^{\mathrm{b}}}^{\mathrm{a}}$} \\
\cline { 5 - 7 } & 1,3 -Diene & $\mathrm{R}^{1}$ & $\mathrm{R}^{2}$ & $\mathbf{7 : 8 ^ { \mathrm { a } }}$ & $\mathbf{7}(d r)^{\mathrm{a}}$ & $\mathbf{8}(d r)^{\mathrm{a}}$ \\
\hline 1 & $\mathbf{6 a}$ & $\mathrm{Cl}$ & $\mathrm{Ph}$ & $70: 30$ & $63(64: 36)$ & $21(66: 34)$ \\
2 & $\mathbf{6 b}$ & $\mathrm{CF}_{3}$ & $\mathrm{Ph}$ & $75: 25$ & $69(65: 35)$ & $27(65: 35)$ \\
3 & $\mathbf{6 c}$ & $\mathrm{NO}_{2}$ & $\mathrm{SiMe}_{3}$ & $>95: 5$ & $80(65: 35)$ & -- \\
4 & $\mathbf{6 d}$ & $\mathrm{CF}_{3}$ & $\mathrm{CH}_{2} \mathrm{SO}_{2} \mathrm{Ph}$ & $30: 70$ & $21(>95: 5)$ & $63(>95: 5)$ \\
\hline
\end{tabular}

${ }^{a}$ Product and diastereomeric ratios $(d r)$ were determined by ${ }^{1} \mathrm{H}$ NMR of the crude product $(500$ $\mathrm{MHz}) .{ }^{\mathrm{b}}$ Yield of isolated products after silica gel chromatography. 
The first reactions were performed with the phenyl substituted 1,3-cyclohexadiene $6 \mathbf{a}\left(\mathrm{R}^{2}\right.$ $=\mathrm{Ph}$ ) (entry 1), affording the hydroperoxides $7 \mathbf{a}$ as main products in $63 \%$ yield. On the other hand, the endoperoxides 8a were isolated only as minor products in $21 \%$ yield. Thus, the photooxygenation of diene 6a proceeds with moderate mode selectivity. This result can be rationalized by the "large-group-effect" of the phenyl group, ${ }^{1 a}$ activating the adjacent methylene group for an ene-reaction. Even more interesting are the diastereoselectivities of the photooxygenation, since stereoisomers of hydroperoxide 7a and endoperoxide 8a were obtained in almost the same ratio ( $d r$ 64:36 and 66:34) (entry 1). The relative configurations of the newly formed stereocenters were determined by NOE measurements (Figure 1)

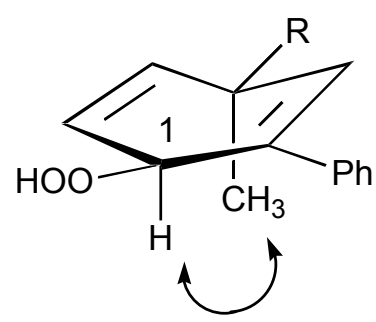

$7 a$

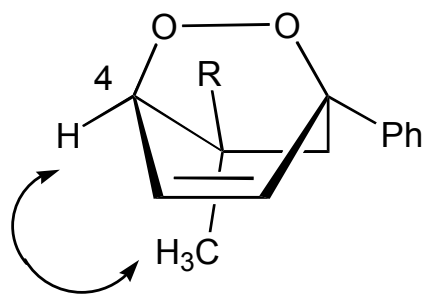

$8 a$

Figure 1. Characteristic NOE contacts in the main hydroperoxide 7a and endoperoxide 8a.

Distinct NOE contacts between the methyl group and H-1 of the main hydroperoxide 7a and $\mathrm{H}-4$ of the main endoperoxide $8 \mathbf{a}$ indicate the preferential attack of ${ }^{1} \mathrm{O}_{2}$ from the side of the benzylic alcohol. This result can be rationalized by a stabilizing hydrogen bridge between the $\mathrm{OH}$ group and the negatively charged oxygen in a perepoxide intermediate, which is in accordance with the photooxygenation of allylic ${ }^{3 \mathrm{a}}$ and homoallylic ${ }^{8 \mathrm{~b}}$ alcohols. However, due to the flexibility of 1,3-cyclohexadienes, ${ }^{11}$ the diastereomeric ratio $(d r)$ of the products are only 64:36 and 66:34 (Table 1, entry 1).

To further increase the stereoselectivities, we subsequently investigated the influence of para substituents at the aromatic ring of the benzylic alcohol (entry 2). Thus, an electron acceptor $\left(\mathrm{R}^{1}=\mathrm{CF}_{3}\right)$ should strengthen the postulated hydrogen bridge to singlet oxygen, resulting in a preferential attack syn to the $\mathrm{OH}$ group. However, almost the same stereo- and mode selectivity was observed in the photooxygenation (entry 2), which might be due to the remote position of the substituent.

On the other hand, a remarkable result is the almost identical diastereoselectivity ( $d r$ 65:35) for all products $\mathbf{7 a}, \mathbf{8 a}, \mathbf{7 b}$ and $\mathbf{8 b}$, irrespective of an ene-reaction or [4+2]-cycloaddition (Table 1, entries 1 and 2). This gives clear evidence for a common perepoxide intermediate in both reaction modes, which is interesting for the mechanism of ${ }^{1} \mathrm{O}_{2}$ reactions and is in accordance with our studies on the photooxygenation of 1,2-dihydronaphthalenes. ${ }^{12}$ Thus, in the first step the perepoxides $\mathbf{9 a}, \mathbf{b}$ are formed by attack of the electrophilic ${ }^{1} \mathrm{O}_{2}$ to the phenyl substituted double bond (Scheme 3). This step controls the stereoselectivities of all further 
pathways and explains the similar diastereomeric ratios for all products.

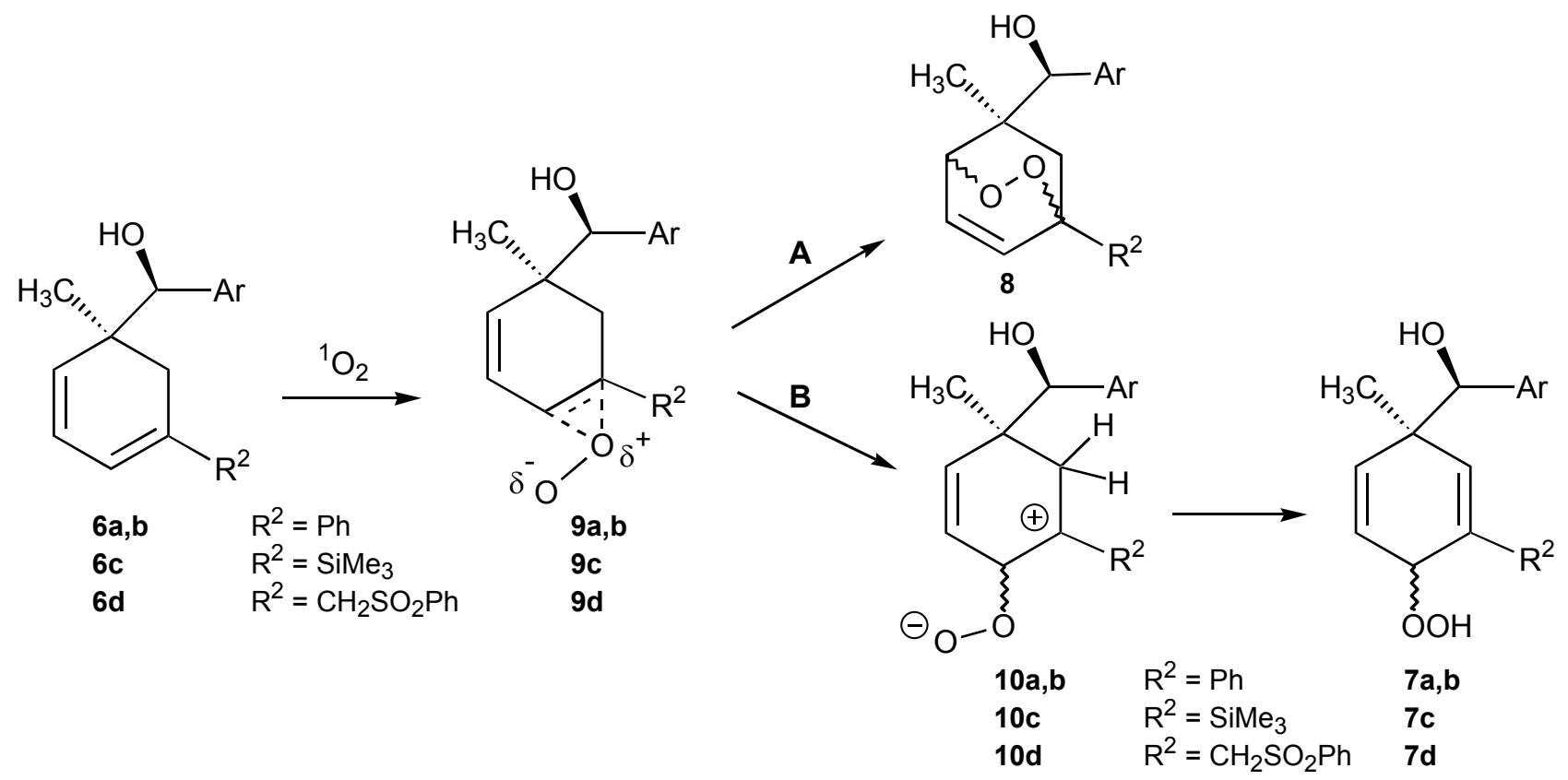

\section{Scheme 3}

The perepoxide intermediates 9 can directly react to the endoperoxides 8 by attack of the terminal oxygen atom to the adjacent double bond (pathway A). However, heterolysis to the zwitterions $\mathbf{1 0}$ might compete (pathway $\mathbf{B}$ ), which is favored by the stabilizing propensity of the phenyl group $\left(\mathrm{R}^{2}=\mathrm{Ph}\right)$ on the positively charged carbon atom. Finally, tautomerization affords the hydroperoxides $\mathbf{7 a}, \mathbf{b}$. This mechanistic rational explains the mode selectivity in favor of the hydroperoxides $(\mathbf{7}: \mathbf{8}=70: 30$, entry 1 and 75:25, entry 2, Table 1$)$.

To shift the mode selectivity to the side of the hydroperoxides, we investigated the photooxygenation of the silyl substituted 1,3-cyclohexadiene $\mathbf{6 c}\left(\mathrm{R}^{2}=\mathrm{SiMe}_{3}\right)$, since the "large group effect" of the silyl group strongly activates the geminal position. ${ }^{1 \mathrm{a}}$ Indeed, now pathway $\mathbf{B}$ afforded only hydroperoxides $\mathbf{7} \mathbf{c}$ as sole oxidation products (Table 1, entry 3 ) and the formation of endoperoxides 8c (pathway A) could not compete, which is in accordance to our mechanistic rational. The diastereomeric ratio $(d r)$ is again 65:35 in favor of a syn attack of ${ }^{1} \mathrm{O}_{2}$ to the $\mathrm{OH}$ group.

Finally, alkyl substitutents should stabilize the zwitterions $\mathbf{1 0}$ less effectively than phenyl groups. Therefore, we investigated the photooxygenation of 1,3-cyclohexadiene $\mathbf{6 d}\left(\mathrm{R}^{2}=\right.$ $\mathrm{CH}_{2} \mathrm{SO}_{2} \mathrm{Ph}$ ), which bears an additional acceptor. Indeed, the mode selectivity is now in favor of the endoperoxide (7d:8d $=30: 70$, Table 1 , entry 4). Thus, different substituents strongly influence the product distribution from $>95: 5\left(\mathrm{R}^{2}=\mathrm{SiMe}_{3}\right)$ to $30: 70\left(\mathrm{R}^{2}=\mathrm{CH}_{2} \mathrm{SO}_{2} \mathrm{Ph}\right)$.

A very interesting result is the high diastereoselectivity of the photooxygenation of the 1,3cyclohexadiene 6d (entry 4) in contrast to all other substrates (entries 1-3). Thus, the 
hydroperoxide 7d and endoperoxide 8d were isolated in high yields in diastereomerically pure form. Furthermore, ${ }^{1} \mathrm{O}_{2}$ attacks the diene from exactly the opposite face (anti to the $\mathrm{OH}$ group), which was confirmed by NOESY and distinct NOE contacts between the benzylic proton and H1 of the hydroperoxide 7d and H-4 of the endoperoxide 8d (Figure 2).

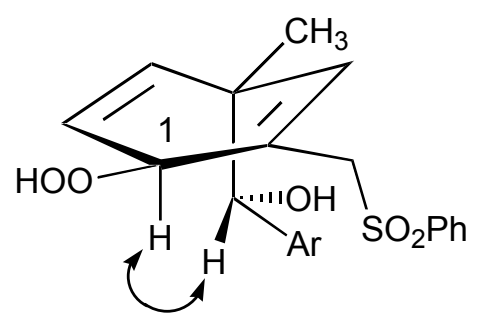

7d

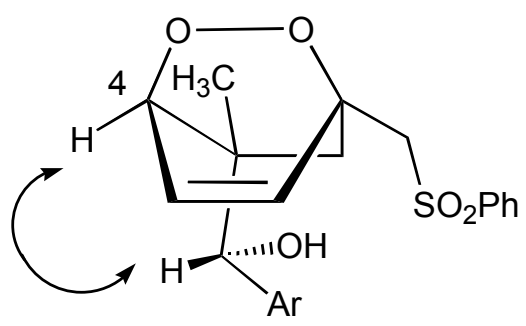

8d

Figure 2. Characteristic NOE contacts in the hydroperoxide 7d and endoperoxide $\mathbf{8 d}$.

Therefore, the high stereoselectivity cannot be due to the interaction of ${ }^{1} \mathrm{O}_{2}$ with the benzylic alcohol during the photooxygenation. We explain this remarkable result by the conformation of the starting material $\mathbf{6 d}$. The $\mathrm{OH}$ group and the phenyl sulfone can form an intramolecular hydrogen bridge, which was established by X-ray analysis (Figure 3). ${ }^{10}$

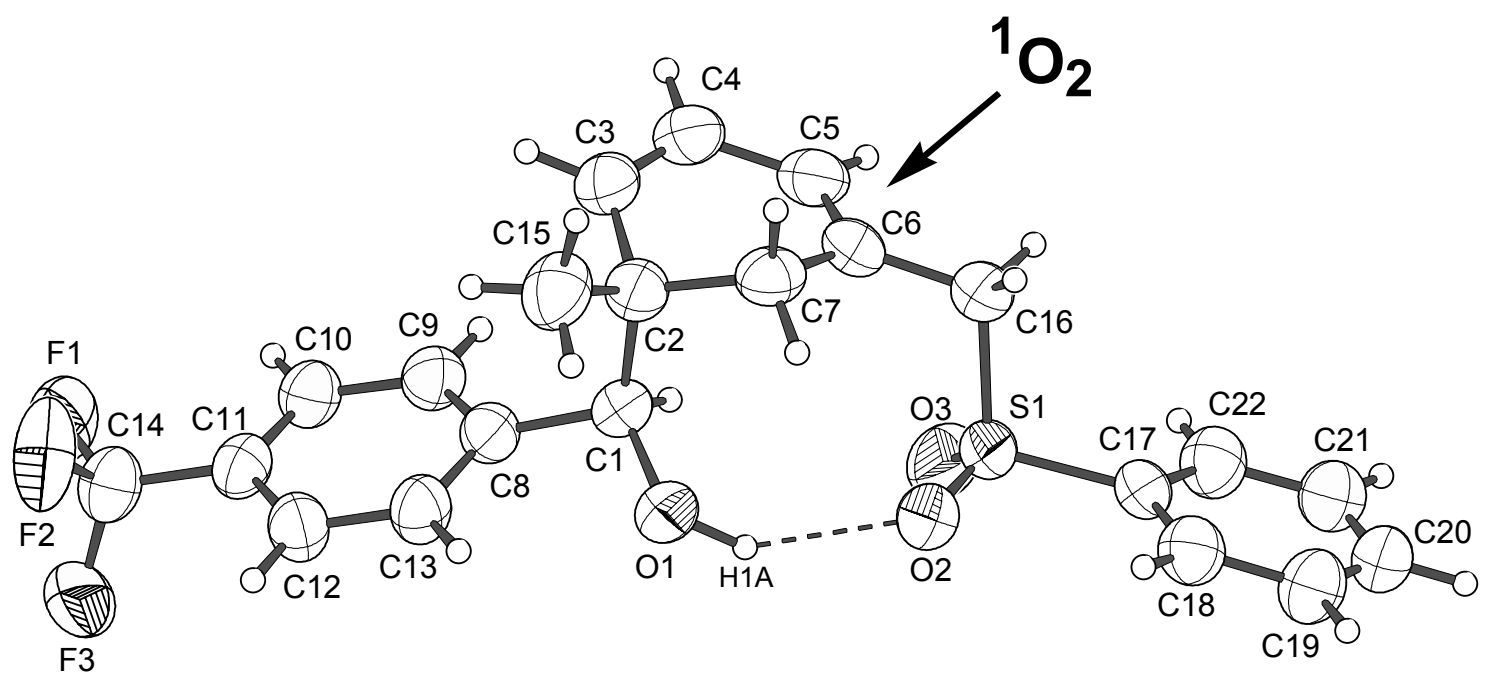

Figure 3. Crystal structure of 1,3-cyclohexadiene $\mathbf{6} \mathbf{d}^{10}$ and preferred attack of ${ }^{1} \mathrm{O}_{2}$.

This does not only block the alcohol for coordination with singlet oxygen, but also shields one face of the 1,3-cyclohexadiene 6d efficiently. Therefore, the photooxygenation can occur only from the less hindered side, irrespective of the reaction mode. Such severe steric interactions by hydrogen bonding were hitherto unknown in singlet oxygen reactions. Finally, 
especially the endoperoxide $\mathbf{8 d}$ is not only of mechanistic but also of synthetic interest, since starting from the boron-functionalized 1,3-diene $\mathbf{3}$ and other simple precursors, four stereogenic centers are constructed in only few steps with high selectivity.

In summary, the photooxygenation of chiral 1,3-cyclohexadienes affords hydroperoxides and endoperoxides in high yields. Substituents at the double bond strongly influence the mode selectivity of the reactions. The same diastereoselectivity for ene-reaction and [4+2]cycloaddition gives evidence for common perepoxide intermediates. Finally, the photooxygenation of a methylensulfonyl substituted 1,3-cyclohexadiene proceeds with very high diastereoselectivity, which can be explained by an intramolecular hydrogen bridge, shielding one face of the compound. Future work will focus on synthetic applications of these new oxidation reactions, generating four stereogenic centers in only few steps from simple precursors.

\section{Experimental Section}

General Procedures. Commercially available compounds were used without further purification; solvents were dried according to standard procedures. Flash chromatography was performed using Merck Kieselgel 60 silica. TLC analysis was carried out on Alugram silica gel $60 \mathrm{~F}_{254}$ plates (Macherey-Nagel). Potassium iodide was used as developing reagent for the peroxide products. NMR spectra were measured on a Bruker AC $300(300 \mathrm{MHz})$ and AC 500 $(500 \mathrm{MHz})$ spectrometer using deuterochloroform $\left(\mathrm{CDCl}_{3}\right)$ as internal standard. IR spectra were recorded on a Perkin Elmer 1600 FT-IR and elemental analysis were performed on a Vario El 3 instrument (Elementar).

\section{General procedure for the cobalt-catalyzed Diels-Alder / allylboration reaction sequence} Anhydrous zinc iodide (60 mol\%), zinc dust (60 mol\%) and $\mathrm{CoBr}_{2}(\mathrm{dppe})(10 \mathrm{~mol} \%)$ were stirred under argon in $0.5 \mathrm{~mL}$ DCM until the green suspension turned brown (5-10 min). Then, the boron diene 1 (1.0 eq.) in DCM (c = $200 \mathrm{mg} / \mathrm{mL})$ and the appropriate alkyne 2 (1.0 eq.) were added and the mixture was stirred at room temperature. After $30 \mathrm{~min}$ the aldehyde (1.0 eq.) was added and the reaction was stirred at room temperature for $15 \mathrm{~h}$. The suspension was diluted with MTBE and washed with $1 \mathrm{M}$ aqueous $\mathrm{NaOH}$ and saturated $\mathrm{NaHSO}_{3}$ solution. After drying with $\mathrm{MgSO}_{4}$ the solution was filtered over a short pad of silica gel and then the solvent was removed under vacuum. The residue was then purified by flash column chromatography (pentane/MTBE). For analytical data see reference 10.

\section{General photooxygenation procedure}

The 1,3-cyclohexadienes 1a-d and tetraphenylporphin $(1 \mathrm{mg})$ were dissolved in $\mathrm{CDCl}_{3}(3 \mathrm{~mL})$ in a glass tube. A slow stream of oxygen was bubbled through the solution and the tube was irradiated at $-30{ }^{\circ} \mathrm{C}$ with two sodium lamps $(250 \mathrm{~W})$. After $10 \mathrm{~min}$ tlc (hexane / ethyl acetate $2: 1)$ showed complete conversion. The ratio of the isomers was directly determined from the NMR spectra $(500 \mathrm{MHz})$ of the crude reaction mixture and the oxidation products were isolated by column chromatography. 


\section{Numbering of compounds and ring carbon atoms}

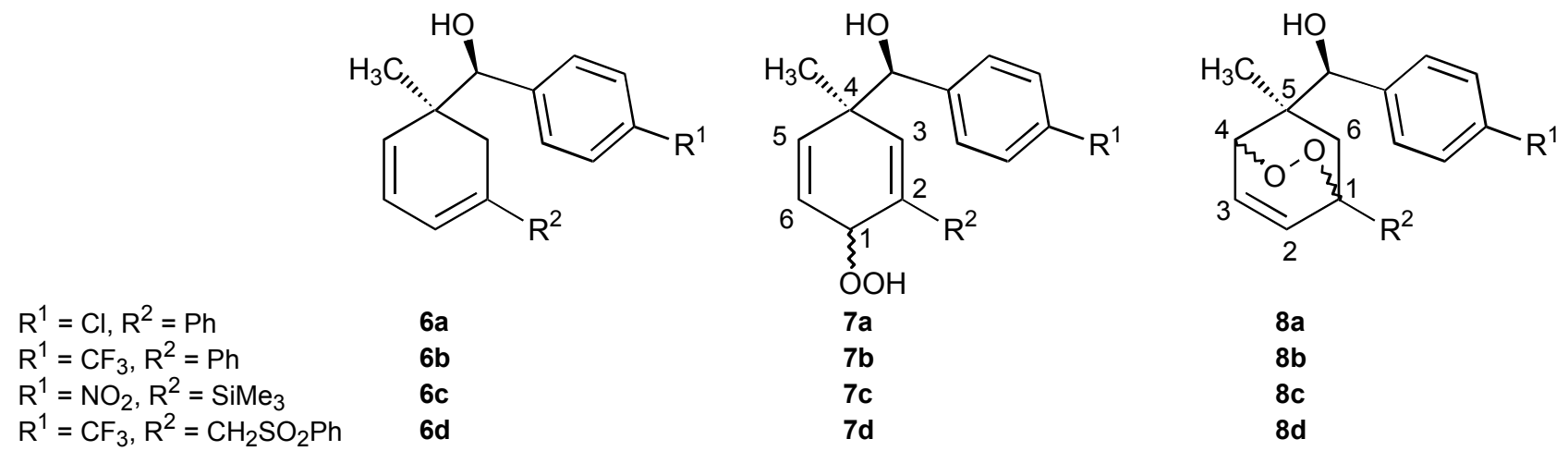

Photooxygenation of 1,3-cyclohexadiene (6a). The photooxygenation of 1,3-cyclohexadiene 6a $(132 \mathrm{mg}, 0.42 \mathrm{mmol})$ afforded a crude product mixture $(140 \mathrm{mg})$ of hydroperoxides $7 \mathbf{a}(d r=$ 64:36) and endoperoxides 8a $(d r=66: 34)$ in a ratio of 70:30. Column chromatography (hexane / ethyl acetate $4: 1)$ yielded $20 \mathrm{mg}(14 \%)$ of the main endoperoxide $8 \mathbf{a}\left(\mathrm{R}_{\mathrm{f}}=0.61\right), 10 \mathrm{mg}(7 \%)$ of the minor endoperoxide $\mathbf{8 a}\left(\mathrm{R}_{\mathrm{f}}=0.46\right), 30 \mathrm{mg}(21 \%)$ of the minor hydroperoxide $7 \mathbf{a}\left(\mathrm{R}_{\mathrm{f}}=\right.$ $0.36)$ and $60 \mathrm{mg}(42 \%)$ of the main hydroperoxide $7 \mathbf{a}\left(\mathrm{R}_{\mathrm{f}}=0.25\right)$ as colorless oils.

Main hydroperoxide 7a. ${ }^{1} \mathrm{H}-\mathrm{NMR}\left(300 \mathrm{MHz}, \mathrm{CDCl}_{3}\right) \delta 1.15\left(\mathrm{~s}, 3 \mathrm{H}, \mathrm{CH}_{3}\right), 1.59,2.08$ (each bs, 1H, OH, OOH), 4.58 (bs, 1H, CHOH), 5.11 (dd, $J=3.0,1.2 \mathrm{~Hz}, 1 \mathrm{H}, \mathrm{H}-1), 6.05$ (d, $J=1.2 \mathrm{~Hz}$, $1 \mathrm{H}, 3-\mathrm{H}), 6.08$ (dt, $J=9.9,1.2 \mathrm{~Hz}, 1 \mathrm{H}, 5-\mathrm{H}), 6.18(\mathrm{dd}, J=9.9,3.0 \mathrm{~Hz}, 1 \mathrm{H}, 6-\mathrm{H}), 7.20-7.50$ (m, 9H, H-arom.); ${ }^{13} \mathrm{C}-\mathrm{NMR}\left(75 \mathrm{MHz}, \mathrm{CDCl}_{3}\right) \delta 23.6$ (q, $\left.\mathrm{CH}_{3}\right), 44.5$ (s, C-4), 76.3 (d, CHOH), 80.2 (d, C-1), 124.4 (q, $\mathrm{CF}_{3}$ ), 126.2, 126.4, 127.7, 128.0, 128.5, 133.8, 134.6, 135.7 (each d, C-3, C-5, C-6, C-arom.), 124.9, 128.2, 139.3, 145.0 (each s, C-2, C-arom.); IR (KBr) 3420, 2982, 2940, 1740, 1445, 1395, 1221, 1127, 1022, $939 \mathrm{~cm}^{-1}$; Anal. Calcd for $\mathrm{C}_{20} \mathrm{H}_{19} \mathrm{ClO}_{3}: \mathrm{C}, 70.07$; H, 5.59; Found: C, 70.32; H, 5.80.

Minor hydroperoxide 7a. ${ }^{1} \mathrm{H}-\mathrm{NMR}\left(300 \mathrm{MHz}, \mathrm{CDCl}_{3}\right) \delta 1.07\left(\mathrm{~s}, 3 \mathrm{H}, \mathrm{CH}_{3}\right), 1.63,3.34$ (each bs, $1 \mathrm{H}, \mathrm{OH}, \mathrm{OOH}), 4.58$ (bs, $1 \mathrm{H}, \mathrm{CHOH}), 5.41$ (d, $J=3.8,1.2 \mathrm{~Hz}, 1 \mathrm{H}, \mathrm{H}-1), 5.97$ (d, $J=1.8 \mathrm{~Hz}$, $1 \mathrm{H}, 3-\mathrm{H}), 6.11$ (dd, $J=9.9,1.2 \mathrm{~Hz}, 1 \mathrm{H}, 5-\mathrm{H}), 6.22$ (dd, $J=9.9,3.9 \mathrm{~Hz}, 1 \mathrm{H}, 6-\mathrm{H}), 7.20-7.60$ (m, 9H, H-arom.); ${ }^{13} \mathrm{C}-\mathrm{NMR}\left(75 \mathrm{MHz}, \mathrm{CDCl}_{3}\right) \delta 24.5$ (q, $\left.\mathrm{CH}_{3}\right), 44.0$ (s, C-4), 77.2 (d, CHOH), 79.7 (d, C-1), 125.2 (q, $\mathrm{CF}_{3}$ ), 125.8, 126.0, 127.4, 127.7, 128.2, 133.8, 134.6, 135.8 (each d, C-3, C-5, C-6, C-arom.), 133.8, 135.6, 138.5 (each s, C-2, C-arom.); IR (KBr) 3420, 2982, 2940, 1740, $1445,1395,1221,1127,1022,939 \mathrm{~cm}^{-1}$.

Main endoperoxide 8a. ${ }^{1} \mathrm{H}-\mathrm{NMR}\left(300 \mathrm{MHz}, \mathrm{CDCl}_{3}\right) \delta 0.82\left(\mathrm{~s}, 3 \mathrm{H}, \mathrm{CH}_{3}\right), 1.67(\mathrm{~d}, J=13.2 \mathrm{~Hz}$, $1 \mathrm{H}, 6-\mathrm{H}), 2.75$ (d, $J=2.5 \mathrm{~Hz}, 1 \mathrm{H}, \mathrm{OH}), 2.84$ (d, $\left.J=13.2 \mathrm{~Hz}, 1 \mathrm{H}, 6^{\prime}-\mathrm{H}\right), 4.22$ (dd, $J=5.4,1.8$ $\mathrm{Hz}, 1 \mathrm{H}, 4-\mathrm{H}), 5.18$ (d, $J=2.5 \mathrm{~Hz}, 1 \mathrm{H}, \mathrm{CHOH}), 6.69$ (dd, $J=7.8,5.4 \mathrm{~Hz}, 1 \mathrm{H}, 3-\mathrm{H}), 6.71(\mathrm{dd}, J=$ 7.8, $1.8 \mathrm{~Hz}, 1 \mathrm{H}, 2-\mathrm{H}), 7.20-7.60$ (m, 9H, H-arom.); ${ }^{13} \mathrm{C}-\mathrm{NMR}\left(75 \mathrm{MHz}, \mathrm{CDCl}_{3}\right) \delta 20.0$ (q, $\mathrm{CH}_{3}$ ), 29.7 (t, C-6), 40.9 (s, C-5), 77.4 (d, CHOH), 78.4 (d, C-4), 79.1 (s, C-1), 124.9 (q, $\left.\mathrm{CF}_{3}\right)$, 126.0, 126.7, 128.3, 128.7, 132.4, 134.6, 135.7 (each d, C-2, C-3, C-arom.), 128.1, 139.3, 145.0 (each s, 
C-arom.); IR (KBr) 3420, 2982, 2940, 1740, 1445, 1395, 1221, 1127, 1022, $939 \mathrm{~cm}^{-1}$; Anal. Calcd for $\mathrm{C}_{20} \mathrm{H}_{19} \mathrm{ClO}_{3}$ : C, 70.07; H, 5.59; Found: C, 70.33; H, 5.34.

Minor endoperoxide 8a. ${ }^{1} \mathrm{H}-\mathrm{NMR}\left(300 \mathrm{MHz} \mathrm{CDCl}_{3}\right) \delta 1.36\left(\mathrm{~s}, 3 \mathrm{H}, \mathrm{CH}_{3}\right), 1.85(\mathrm{bs}, 1 \mathrm{H}, \mathrm{OH})$, $2.18(\mathrm{~d}, J=13.3 \mathrm{~Hz}, 1 \mathrm{H}, 6-\mathrm{H}), 2.21$ (d, $\left.J=13.3 \mathrm{~Hz}, 1 \mathrm{H}, 6^{\prime}-\mathrm{H}\right), 3.88$ (dd, $J=5.8,1.3 \mathrm{~Hz}, 1 \mathrm{H}, 4-$ H), 4.44 (bs, 1H, CHOH), 6.78 (dd, $J=8.3,1.3 \mathrm{~Hz}, 1 \mathrm{H}, 2-\mathrm{H}), 6.93$ (dd, $J=8.3,5.8 \mathrm{~Hz}, 1 \mathrm{H}, 3-$ H), 7.20-7.60 (m, 9H, H-arom.); ${ }^{13} \mathrm{C}-\mathrm{NMR}\left(75 \mathrm{MHz}, \mathrm{CDCl}_{3}\right) \delta 20.0$ (q, $\left.\mathrm{CH}_{3}\right), 29.7$ (t, C-6), 40.9 (s, C-5), 77.4 (d, CHOH), 78.4 (d, C-4), 79.1 (s, C-1), 124.9 (q, $\left.\mathrm{CF}_{3}\right), 126.0,126.7,128.3,128.7$, 132.4, 134.6, 135.7 (each d, C-2, C-3, C-arom.), 128.1, 139.3, 145.0 (each s, C-arom.); IR (KBr) 3420, 2982, 2940, 1740, 1445, 1395, 1221, 1127, 1022, $939 \mathrm{~cm}^{-1}$.

Photooxygenation of 1,3-cyclohexadiene 6b. The photooxygenation of 1,3-cyclohexadiene $\mathbf{6 b}$ $(67 \mathrm{mg}, 0.19 \mathrm{mmol})$ afforded a crude product mixture $(75 \mathrm{mg})$ of hydroperoxides $7 \mathbf{b}(d r=65: 35)$ and endoperoxides $\mathbf{8 b}(d r=65: 35)$ in a ratio of 75:25. Column chromatography (hexane / ethyl acetate $4: 1)$ yielded $20 \mathrm{mg}(27 \%)$ of the main endoperoxide $8 \mathbf{b}\left(\mathrm{R}_{\mathrm{f}}=0.43\right), 32 \mathrm{mg}(44 \%)$ of a mixture of both hydroperoxides $7 \mathbf{b}\left(\mathrm{R}_{\mathrm{f}}=0.2-0.3\right)$ and $18 \mathrm{mg}(25 \%)$ of the pure main hydroperoxide $7 \mathbf{b}\left(\mathrm{R}_{\mathrm{f}}=0.16\right)$ as colorless oils.

Main hydroperoxide $7 \mathbf{b} .{ }^{1} \mathrm{H}-\mathrm{NMR}\left(300 \mathrm{MHz}, \mathrm{CDCl}_{3}\right) \delta 1.17\left(\mathrm{~s}, 3 \mathrm{H}, \mathrm{CH}_{3}\right), 3.35,3.60$ (each bs, $1 \mathrm{H}, \mathrm{OH}, \mathrm{OOH}), 4.65$ (bs, $1 \mathrm{H}, \mathrm{CHOH}), 5.08$ (ddd, $J=3.1,2.0,1.5 \mathrm{~Hz}, 1 \mathrm{H}, \mathrm{H}-1), 6.03$ (d, $J=1.5$ $\mathrm{Hz}, 1 \mathrm{H}, 3-\mathrm{H}), 6.09$ (dd, $J=10.0,2.0 \mathrm{~Hz}, 1 \mathrm{H}, 5-\mathrm{H}), 6.19$ (dd, $J=10.0,3.1 \mathrm{~Hz}, 1 \mathrm{H}, 6-\mathrm{H}), 7.20-$ 7.60 (m, 9H, H-arom.); ${ }^{13} \mathrm{C}-\mathrm{NMR}\left(75 \mathrm{MHz}, \mathrm{CDCl}_{3}\right) \delta 23.6$ (q, $\left.\mathrm{CH}_{3}\right), 44.5$ (s, C-4), 76.3 (d, $\mathrm{CHOH}), 80.2$ (d, C-1), 124.4 (q, $\left.\mathrm{CF}_{3}\right), 126.2,126.4,127.7,128.0,128.5,133.8,134.6,135.7$ (each d, C-3, C-5, C-6, C-arom.), 124.9, 128.2, 139.3, 145.0 (each s, C-2, C-arom.); IR (KBr) 3423, 2855, 1620, 1460, 1326, 1166, 1124, 1066, 759, 698, $608 \mathrm{~cm}^{-1}$; Anal. Calcd for $\mathrm{C}_{21} \mathrm{H}_{19} \mathrm{~F}_{3} \mathrm{O}_{3}$ : C, 67.02; H, 5.09; Found: C, 66.82; H, 5.12.

Minor hydroperoxide 7b. ${ }^{1} \mathrm{H}-\mathrm{NMR}\left(300 \mathrm{MHz}, \mathrm{CDCl}_{3}\right) \delta 1.07\left(\mathrm{~s}, 3 \mathrm{H}, \mathrm{CH}_{3}\right), 3.41,3.70($ each bs, $1 \mathrm{H}, \mathrm{OH}, \mathrm{OOH}), 4.49$ (bs, 1H, CHOH), 5.39 (dd, $J=4.0,1.9 \mathrm{~Hz}, 1 \mathrm{H}, \mathrm{H}-1), 5.94$ (d, $J=1.9 \mathrm{~Hz}$, 1H, 3-H), 6.05 (d, $J=10.0 \mathrm{~Hz}, 1 \mathrm{H}, 5-\mathrm{H}), 6.22$ (dd, $J=10.0,4.0 \mathrm{~Hz}, 1 \mathrm{H}, 6-\mathrm{H}), 7.20-7.60$ (m, 9H, H-arom.); ${ }^{13} \mathrm{C}-\mathrm{NMR}\left(75 \mathrm{MHz}, \mathrm{CDCl}_{3}\right) \delta 24.5\left(\mathrm{q}, \mathrm{CH}_{3}\right), 44.0(\mathrm{~s}, \mathrm{C}-4), 77.2(\mathrm{~d}, \mathrm{CHOH}), 79.7$ (d, C-1), 125.2 (q, $\mathrm{CF}_{3}$ ), 125.8, 126.0, 127.4, 127.7, 128.2, 133.8, 134.6, 135.8 (each d, C-3, C-5, C6, C-arom.), 133.8, 135.6, 138.5 (each s, C-2, C-arom.); IR (KBr) 3431, 2971, 1620, 1419, 1327, $1166,1124,1067,851,760,698,609 \mathrm{~cm}^{-1}$.

Endoperoxide 8b. ${ }^{1} \mathrm{H}-\mathrm{NMR}\left(300 \mathrm{MHz}, \mathrm{CDCl}_{3}\right) \delta 0.82\left(\mathrm{~s}, 3 \mathrm{H}, \mathrm{CH}_{3}\right), 1.66(\mathrm{~d}, J=13.4 \mathrm{~Hz}, 1 \mathrm{H}, 6-$ $\mathrm{H}), 2.80(\mathrm{~d}, J=2.5 \mathrm{~Hz}, 1 \mathrm{H}, \mathrm{OH}), 2.85\left(\mathrm{~d}, J=13.4 \mathrm{~Hz}, 1 \mathrm{H}, 6^{\prime}-\mathrm{H}\right), 4.21(\mathrm{dd}, J=6.1,1.5 \mathrm{~Hz}, 1 \mathrm{H}$, 4-H), 5.25 (d, $J=2.5 \mathrm{~Hz}, 1 \mathrm{H}, \mathrm{CHOH}), 6.69$ (dd, $J=8.3,6.1 \mathrm{~Hz}, 1 \mathrm{H}, 3-\mathrm{H}), 6.71$ (dd, $J=8.3,1.5$ $\mathrm{Hz}, 1 \mathrm{H}, 2-\mathrm{H}), 7.20-7.70$ (m, 9H, H-arom.); ${ }^{13} \mathrm{C}-\mathrm{NMR}\left(75 \mathrm{MHz}, \mathrm{CDCl}_{3}\right) \delta 20.0$ (q, $\left.\mathrm{CH}_{3}\right), 29.7$ (t, C-6), 40.9 (s, C-5), 77.4 (d, CHOH), 78.4 (d, C-4), 79.1 (s, C-1), 124.9 (q, CF $), 126.0,126.7$, 128.3, 128.7, 132.4, 134.6, 135.7 (each d, C-2, C-3, C-arom.), 128.1, 139.3, 145.0 (each s, Carom.); IR (KBr) 3494, 2928, 1618, 1449, 1326, 1163, 1113, 1016, $698 \mathrm{~cm}^{-1}$; HRMS Calcd. $\mathrm{C}_{21} \mathrm{H}_{19} \mathrm{~F}_{3} \mathrm{O}_{3} \mathrm{Na}$ : 399.1184; Found: 399.1184 . 
Photooxygenation of 1,3-cyclohexadiene 6c. The photooxygenation of 1,3-cyclohexadiene $\mathbf{6 c}$ $(160 \mathrm{mg}, 0.50 \mathrm{mmol})$ afforded a crude product mixture $(150 \mathrm{mg})$ of hydroperoxides $7 \mathrm{c}(d r=$ 65:35) and no endoperoxide 8c could be detected. Column chromatography (hexane / ethyl acetate $6: 1)$ yielded $20 \mathrm{mg}(11 \%)$ of the pure minor hydroperoxide $7 \mathrm{c}\left(\mathrm{R}_{\mathrm{f}}=0.57\right)$ and $120 \mathrm{mg}$ $(69 \%)$ of a mixture of both hydroperoxides $7 \mathrm{c}\left(\mathrm{R}_{\mathrm{f}}=0.43\right)$ as a white solid $\left(\mathrm{mp} 67-68^{\circ} \mathrm{C}\right)$.

Main hydroperoxide 7c. ${ }^{1} \mathrm{H}-\mathrm{NMR}\left(300 \mathrm{MHz}, \mathrm{CDCl}_{3}\right) \delta 0.09\left(\mathrm{~s}, 9 \mathrm{H}, \mathrm{SiMe}_{3}\right), 1.17\left(\mathrm{~s}, 3 \mathrm{H}, \mathrm{CH}_{3}\right)$, 2,71, 3.60 (each bs, 1H, OH, OOH), 4.45 (bs, 1H, CHOH), 4.57 (dd, J = 2.8, 2.1 Hz, 1H, H-1), $5.86(\mathrm{t}, J=2.1 \mathrm{~Hz}, 1 \mathrm{H}, 3-\mathrm{H}), 5.93(\mathrm{dd}, J=10.1,2.1 \mathrm{~Hz}, 1 \mathrm{H}, 5-\mathrm{H}), 6.13(\mathrm{dd}, J=10.1,2.8 \mathrm{~Hz}, 1 \mathrm{H}$, 6-H), 7.36 (d, $J=8.7 \mathrm{~Hz}, 2 \mathrm{H}, \mathrm{H}$-arom.), 8.08 (d, $J=8.7 \mathrm{~Hz}, 2 \mathrm{H}, \mathrm{H}$-arom.); ${ }^{13} \mathrm{C}-\mathrm{NMR}$ (75 MHz, $\left.\mathrm{CDCl}_{3}\right) \delta-1.5$ (q, $\mathrm{SiMe}_{3}$ ), 23.7 (q, $\mathrm{CH}_{3}$ ), 43.5 (s, C-4), 77.5 (d, CHOH), 79.6 (d, C-1), 122.2, 128.6 (each d, C-arom.), 127.8, 133.5, 143.5 (each d, C-3, C-5, C-6), 137.2, 147.1, 147.7 (each s, C-2, C-arom.); IR (KBr) 3433, 2958, 2872, 1606, 1519, 1348, 1267, 1047, $840 \mathrm{~cm}^{-1}$; Anal. Calcd for $\mathrm{C}_{17} \mathrm{H}_{23} \mathrm{NSiO}_{5}$ : C, 58.43; H, 6.63; N, 4.01; Found: C, 58.60; H, 6.91; N 4.05.

Minor hydroperoxide 7c. ${ }^{1} \mathrm{H}-\mathrm{NMR}\left(300 \mathrm{MHz}, \mathrm{CDCl}_{3}\right) \delta 0.15\left(\mathrm{~s}, 9 \mathrm{H}, \mathrm{SiMe}_{3}\right), 1.01(\mathrm{~s}, 3 \mathrm{H}$, $\mathrm{CH}_{3}$ ), 1.64, 3.35 (each bs, 1H, OH, OOH), 4.61 (d, $\left.J=2.8 \mathrm{~Hz}, 1 \mathrm{H}, \mathrm{CHOH}\right), 4.95$ (dd, $J=3.6 \mathrm{~Hz}$, $1 \mathrm{H}, \mathrm{H}-1), 5.83$ (d, $J=1.4 \mathrm{~Hz}, 1 \mathrm{H}, 3-\mathrm{H}), 6.05$ (dd, $J=10.1,1.4 \mathrm{~Hz}, 1 \mathrm{H}, 5-\mathrm{H}), 6.18$ (dd, $J=10.1$, $3.6 \mathrm{~Hz}, 1 \mathrm{H}, 6-\mathrm{H}), 7.46$ (d, $J=8.8 \mathrm{~Hz}, 2 \mathrm{H}, \mathrm{H}$-arom.), 8.20 (d, $J=8.8 \mathrm{~Hz}, 2 \mathrm{H}, \mathrm{H}$-arom.); ${ }^{13} \mathrm{C}-$ NMR (75 MHz, $\mathrm{CDCl}_{3}$ ) $\delta-1.5$ (q, $\mathrm{SiMe}_{3}$ ), 24.4 (q, $\mathrm{CH}_{3}$ ), 42.8 (s, C-4), 77.1 (d, CHOH), 78.9 (d, C-1), 122.7, 128.6 (each d, C-arom.), 123.3, 126.9, 130.5 (each d, C-3, C-5, C-6), 137.9, 143.6, 147.6 (each s, C-2, C-arom.); IR (KBr) 3445, 2943, 2864, 1612, 1519, 1344, 1258, 1044, 838 $\mathrm{cm}^{-1}$; Anal. Calcd for $\mathrm{C}_{17} \mathrm{H}_{23} \mathrm{NSiO}_{5}$ : C, 58.43; H, 6.63; N, 4.01; Found: C, 58.86; H, 6.31; N 4.23.

Photooxygenation of 1,3-cyclohexadiene 6d. The photooxygenation of 1,3-cyclohexadiene 6d $(266 \mathrm{mg}, 0.63 \mathrm{mmol})$ afforded a crude product mixture $(285 \mathrm{mg})$ of hydroperoxide $7 \mathbf{d}(d r>$ 95:5) and endoperoxides $\mathbf{8 d}(d r=90: 10)$ in a ratio of 30:70. Column chromatography (hexane / ethyl acetate $4: 1)$ yielded $180 \mathrm{mg}(63 \%)$ of the main endoperoxide $\mathbf{8 d}\left(\mathrm{R}_{\mathrm{f}}=0.47\right)$ as white crystals $\left(\mathrm{mp} 64-65^{\circ} \mathrm{C}\right)$ and $60 \mathrm{mg}(21 \%)$ of the hydroperoxide $7 \mathbf{d}\left(\mathrm{R}_{\mathrm{f}}=0.27\right)$ as white crystals (mp $\left.45-46^{\circ} \mathrm{C}\right)$. The minor endoperoxide $8 \mathbf{d}(<10 \%)$ could not be isolated.

Hydroperoxide 7d. ${ }^{1} \mathrm{H}-\mathrm{NMR}\left(300 \mathrm{MHz}, \mathrm{CDCl}_{3}\right) \delta 1.03\left(\mathrm{~s}, 3 \mathrm{H}, \mathrm{CH}_{3}\right), 2.03,2.43$ (each bs, $1 \mathrm{H}$, $\mathrm{OH}, \mathrm{OOH}), 3.75\left(\mathrm{~d}, J=13.9 \mathrm{~Hz}, 1 \mathrm{H}, \mathrm{CH}_{2} \mathrm{~S}\right), 4.17$ (d, $\left.J=13.9 \mathrm{~Hz}, 1 \mathrm{H}, \mathrm{CH}_{2}{ }^{\prime} \mathrm{S}\right), 4.53$ (bs, $1 \mathrm{H}$, $\mathrm{CHOH}), 4.55$ (d, $J=3.0 \mathrm{~Hz}, 1 \mathrm{H}, \mathrm{H}-1), 5.78$ (d, $J=1.5 \mathrm{~Hz}, 1 \mathrm{H}, 3-\mathrm{H}), 5.89$ (dd, $J=10.1,1.5 \mathrm{~Hz}$, $1 \mathrm{H}, 5-\mathrm{H}), 6.02$ (dd, $J=10.1,3.0 \mathrm{~Hz}, 1 \mathrm{H}, 6-\mathrm{H}), 7.25-7.95$ (m, 9H, H-arom.); ${ }^{13} \mathrm{C}-\mathrm{NMR}(75 \mathrm{MHz}$, $\left.\mathrm{CDCl}_{3}\right) \delta 22.8\left(\mathrm{q}, \mathrm{CH}_{3}\right), 44.4(\mathrm{~s}, \mathrm{C}-4), 59.1\left(\mathrm{t}, \mathrm{CH}_{2} \mathrm{~S}\right), 76.7$ (d, $\left.\mathrm{CHOH}\right), 79.7$ (d, C-1), 123.9 (q, C-2), 124.6 (q, $\left.\mathrm{CF}_{3}\right), 125.4,126.1,127.4,128.4,129.3,134.0,135.8,141.2$ (each d, C-3, C-5, C6, C-arom.), 138.8, 143.5 (each s, C-arom.); IR (KBr) 3412, 2929, 1448, 1327, 1162, 1128, 747, $526 \mathrm{~cm}^{-1}$; Anal. Calcd for $\mathrm{C}_{22} \mathrm{H}_{21} \mathrm{~F}_{3} \mathrm{SO}_{5}$ : C, 58.14; H, 4.66; S, 7.05; Found: $\mathrm{C}, 58.14 ; \mathrm{H}, 4.70 ; \mathrm{S}$ 7.03 .

Main endoperoxide 8d. ${ }^{1} \mathrm{H}-\mathrm{NMR}\left(300 \mathrm{MHz}, \mathrm{CDCl}_{3}\right) \delta 1.20\left(\mathrm{~s}, 3 \mathrm{H}, \mathrm{CH}_{3}\right), 1.82(\mathrm{~d}, J=13.5 \mathrm{~Hz}$, $1 \mathrm{H}, 6-\mathrm{H}), 2.15$ (d, $\left.J=13.5 \mathrm{~Hz}, 1 \mathrm{H}, 6^{\prime}-\mathrm{H}\right), 2.69$ (bs, 1H, OH), 3.39 (d, J=14.4 Hz, 1H, $\mathrm{CH}_{2} \mathrm{~S}$ ), $3.46\left(\mathrm{~d}, J=14.4 \mathrm{~Hz}, 1 \mathrm{H}, \mathrm{CH}_{2}{ }^{\prime} \mathrm{S}\right), 3.71(\mathrm{dd}, J=5.8,0.9 \mathrm{~Hz}, 1 \mathrm{H}, 4-\mathrm{H}), 4.36$ (bs, 1H, CHOH), 6.80 
(dd, $J=8.5,5.8 \mathrm{~Hz}, 1 \mathrm{H}, 3-\mathrm{H}), 7.03$ (dd, $J=8.5,0.9 \mathrm{~Hz}, 1 \mathrm{H}, 2-\mathrm{H}), 7.40-7.90$ (m, 9H, H-arom.); ${ }^{13} \mathrm{C}-\mathrm{NMR}\left(75 \mathrm{MHz}, \mathrm{CDCl}_{3}\right) \delta 18.2\left(\mathrm{q}, \mathrm{CH}_{3}\right), 40.1(\mathrm{t}, \mathrm{C}-6), 41.2(\mathrm{~s}, \mathrm{C}-5), 59.5\left(\mathrm{t}, \mathrm{CH}_{2} \mathrm{~S}\right), 75.8(\mathrm{~s}$, C-1), 77.4 (d, CHOH), 78.1 (d, C-4), 125.2 (q, $\mathrm{CF}_{3}$ ), 127.4, 128.0, 129.1, 129.4, 131.8, 132.7, 134.1 (each d, C-2, C-3, C-arom.), 140.3, 144.5 (each s, C-arom.); IR (KBr) 3514, 2976, 1448, 1327, 1156, 1128, $566 \mathrm{~cm}^{-1}$; Anal. Calcd for $\mathrm{C}_{22} \mathrm{H}_{21} \mathrm{~F}_{3} \mathrm{SO}_{5}$ : C, 58.14; H, 4.66; S, 7.05; Found: C, $58.06 ; \mathrm{H}, 4.65 ; \mathrm{S} 7.17$.

\section{Acknowledgements}

This work was generously financed by the Fonds der Chemischen Industrie and the Deutsche Forschungsgemeinschaft (DFG).

\section{References}

1. Recent Reviews: (a) Stratakis, M.; Orfanopoulos, M. Tetrahedron 2000, 56, 1595. (b) Clennan, E. L. Tetrahedron 2000, 56, 9151. (c) Clennan, E. L.; Pace, A. Tetrahedron 2005, 61, 6665 .

2. Review on the photooxygenation of 1,3-dienes: Adam, W.; Griesbeck, A. G. in $C R C$ Handbook of Organic Photochemistry and Photobiology Horspool, W. M., Ed., CRC Press: Boca Raton, 1995, p 311.

3. Excellent Reviews: (a) Prein, M.; Adam, W. Angew. Chem., Int. Ed. 1996, 35, 477. (b) Adam, W.; Prein, M. Acc. Chem. Res. 1996, 29, 275.

4. (a) Schenck, G. O. Angew. Chem. 1952, 64, 12. (b) Matusch, R.; Schmidt, G. Angew. Chem., Int. Ed. 1988, 27, 717. (c) Matusch, R.; Schmidt, G. Helv. Chim. Acta 1989, 72, 51.

5. (a) Dussault, P. H.; Woller, K. R.; Hillier, M. C. Tetrahedron 1994, 50, 8929. (b) Adam, W.; Güthlein, M.; Peters, E.-M.; Peters, K.; Wirth, T. J. Am. Chem. Soc. 1998, 120, 4091. (c) Adam, W.; Bosio, S. G.; Turro, N. J. J. Am. Chem. Soc. 2002, 124, 8814. (d) Adam, W.; Bosio, S. G.; Turro, N. J.; Wolff, B. T. J. Org. Chem. 2004, 69, 1704. (e) Fudickar, W.; Vorndran, K.; Linker, T. Tetrahedron 2006, 62, in press.

6. (a) Sundén, H.; Engqvist, M.; Casas, J.; Ibrahem, I.; Córdova, A. Angew. Chem., Int. Ed. 2004, 43, 6532. (b) Córdova, A.; Sundén, H.; Engqvist, M.; Ibrahem, I.; Casas, J. J. Am. Chem. Soc. 2004, 126, 8914.

7. (a) Fudickar, W.; Fery, A.; Linker, T. J. Am. Chem. Soc. 2005, 127, 9386. (b) Fudickar, W.; Linker, T. Chem. Eur. J. 2006, 12, in press.

8. (a) Linker, T.; Fröhlich, L. Angew. Chem., Int. Ed. 1994, 33, 1971. (b) Linker, T.; Fröhlich, L. J. Am. Chem. Soc. 1995, 117, 2694. (c) Nardello, V.; Aubry, J.-M.; Linker, T.

Photochem. Photobiol. 1999, 70, 524. (d) Fröhlich, L.; Linker, T. Synlett 2004, 2725. 
9. (a) Hilt, G.; Lüers, S.; Smolko, K. I. Org. Lett. 2005, 7, 251. (b) Hilt, G.; Lüers, S.; Harms, K. J. Org. Chem. 2004, 69, 624. (c) Hilt, G.; Smolko, K. I. Angew. Chem., Int. Ed. 2003, 42, 2795.

10. Hilt, G.; Hess, W.; Harms, K. Org. Lett. 2006, 8, 3287.

11. Rabideau, P. W. The Conformational Analysis of Cyclohexenes, Cyclohexadienes, and Related Hydroaromatic Compounds, VCH: Weinheim, 1989.

12. Linker, T.; Rebien, F.; Tóth, G. Chem. Commun. 1996, 2585. 